\title{
Speed Control of Electric Vehicle
}

\author{
A. K. Al-Othman ${ }^{1, *}$, Nabil A. Ahmed ${ }^{2}$, M. E. AlSharidah ${ }^{3}$, K. M. El-Naggar ${ }^{4}$ and Bader N. Alajmi ${ }^{5}$ \\ ${ }^{1, *}$ Electrical Engineering Department, College of Technological Studies, Alrawda, 73452, P.O. Box 33198, Kuwait \\ *Corresponding author
}

\begin{abstract}
Fuel cell based vehicles, when compared to conventional vehicles, are relatively more efficient in terms of energy conversion and do not pose any threat to climate due to no emissions of hazardous gases. An implementation of speed control of electric vehicle is proposed in this paper.
\end{abstract}

Keywords-electric vehicles; boost converter; fuel cell; dSPACE

\section{INTRODUCTION}

Fuel cells (FCs) are devices that convert chemical energy directly and continuously into electrical energy. The elements of the reaction are pure hydrogen (fuel), oxidant, and oxygen, whereas water, heat and electricity are the products of the reaction. Principally, FCs are direct single stage energy conversion devices that relatively provide high electrical energy conversion efficiency. FCs systems, offer a clean alternative for energy production and are considered one of the most promising technologies to be used in the near future as power supply sources, in various portable applications [1-5]. The FCs have characteristic features, such as high efficiency, zero/low pollutant emissions and fuel flexibility, which makes it an extremely desirable option for future power generation. There are many types of fuel cells; e.g., proton exchange membrane (PEM), solid oxide (SO) and molten carbonate (MC). The PEM fuel cell, in particular, has been widely employed in distributed generators and portable applications, due to its reliability in suppling power during steady state operation [6-10]. Over the past two decades, investigation of PEM fuel cells has risen dramatically $[1,11]$. Such interest is driven by technology developments in membrane technology, which eventually improved PEM fuel cell performance. In addition, the use of more efficient catalysts made PEM fuel cells more amenable to operation with methanol through new bimetallic electro catalysts. That in turn led to a major reduction in their cost. PEM fuel cells have been targeted as a likely power plant for hybrid electric vehicles and a viable replacement of internal combustion (IC) engine in alternative energy transportation applications [5, 12-14].

In this paper an application of dSPACE DS1103 to control the speed of a separately exited DC motor fed by (PEM) fuel cell is proposed. The control scheme has been developed using MATLAB/Simulink toolbox. The dSPACE DSP allows for both data acquisition and implementation of control scheme in real time. The instantaneous motor speed is measured and compared to a preset desired reference speed. The error is amplified via Proportional-Integral (PI) controller in an effort to accommodate any disturbance in the speed, and consequently, a proper PWM triggering signal is generated to control the IGBT switch of the Boost converter for voltage regulation to achieve real time speed control of DC motor.

\section{CIRCUITS DESCRIPTIONS AND PRINCIPLE OF OPERATION}

Typically, an electric vehicle is a vehicle supplied by an electrical source. The power bus is a dc link between source and load. FCs that produce dc voltage outputs can be connected to electric power networks through power conditioning units such as DC-DC and DC-AC inverters. The schematic diagram and the system configuration of a FC powered boost DC-DC converter fed separately exited DC motor is shown in Figure 1.

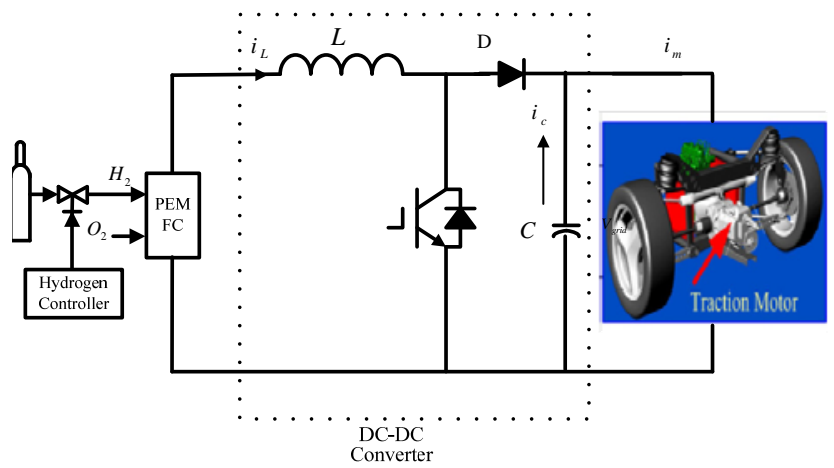

FIGURE I. SYSTEM CONFIGURATION OF BOOST CONVERTER FED ELECTRIC VEHICLE.

\section{RESULTS AND DISCUSSION}

To verify the principle of operation and the accuracy of the results of the proposed system, a prototype is built in the laboratory and checked for different case studies. The system configuration for the experimental setup is divided into two parts: the dSPACE DS1103-based digital signal processor and the power circuit. The dSPACE-based control board enables software flexibility and allows implementation of the proposed control. The power circuit prototype rating of $1.0 \mathrm{~kW}(200 \mathrm{~V}$, 5A) has been implemented using POWEREX CM150DY-12H IGBT as the boost switch, CS241210 fast recovery diode and DC motor rated $1.0 \mathrm{~kW}, 200 \mathrm{~V}, 5 \mathrm{~A}, 1500 \mathrm{rpm}$ coupled to a DC generator as an electric load. The switching frequency used is $10 \mathrm{kHz}$. Ballard Nexa 310-0027 PEM FC power module is used in this study as a power source.

In order to evaluate the transient response and tracking performance of the proposed system, a speed reference pattern was carried out sequentially with speed profile. Each command lasts 20 seconds and after each elapsed period, the 
speed reference is changed. The transient response of the variable states (vehicle side) is presented in below.

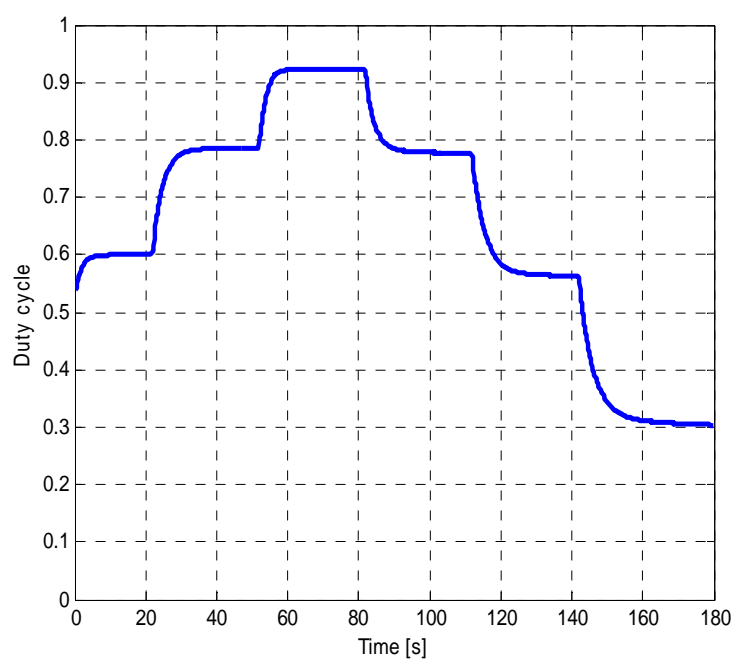

FIGURE II. PERformance Of Vehicle Duty CyCle

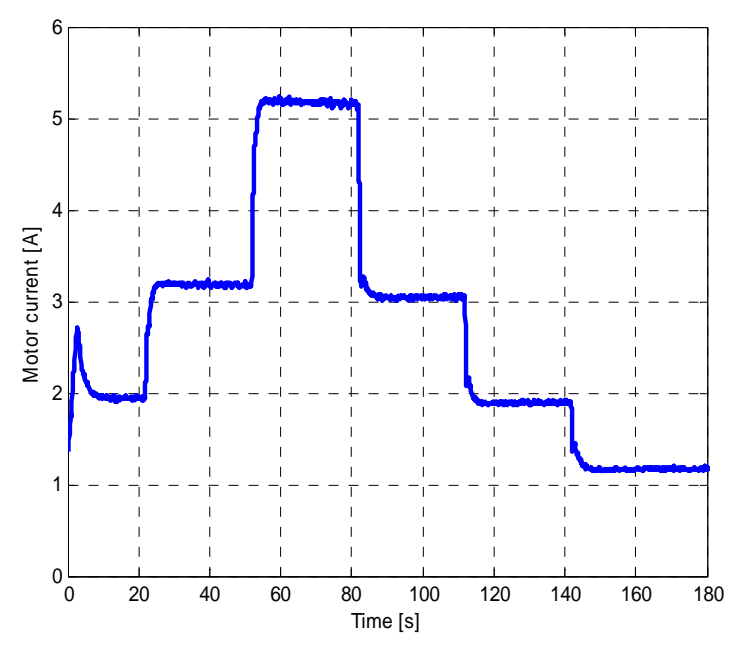

FIGURE III. PERFORMANCE OF VEHICLE CURRENT

\section{CONCLUSION}

A practical implementation of dSPACE control board for speed control of a PEM fuel cell fed electric vehicle is presented in this paper. The experimental outcomes proved that the proposed setup is efficient, accurate and above all environmentally suitable due to a reduced amount of carbon dioxide (CO2) emission for a given power output.

\section{ACKNOWLEDGMENT}

This work is supported and funded by The Public Authority for Applied Education and Training, Research Project No(TS-15-03) dSPACE Control of PEM Fuel Cell for Speed Control of DC Motor.

\section{REFERENCES}

[1] J. Jia, Q. Li, Y. Wang, Y. T. Cham, and M. Han, "Modeling and Dynamic Characteristic Simulation of Proton Exchange Membrane Fuel Cell," IEEE Trans. Control Syst. Technol, vol. 24. 16. pp. 283-291, 2009.

[2] M. Ceraolo, C. Miulli, and A. Pozio, "Modelling Static and Dynamic Behaviour of Proton Exchange Membrane Fuel Cells on the Basis of Electro-chemical Description," Journal of Power Sources, vol. 113. 1. pp. 131-144, 2003.

[3] J. C. Amphlett, R. F. Mann, B. A. Peppley, P. R. Roberge, and A. Rodrigues, "A Model Predicting Transient Responses of Proton Exchange Membrane Fuel Cells," Journal of Power Sources, vol. 61. 1/2. pp. 183-188, 1996.

[4] R. J. Talj, D. Hissel, R. Ortega, M. Becherif, and M. Hilairet, "Experimental Validation of a PEM Fuel-Cell Reduced-Order Model and a Moto-Compressor Higher Order Sliding-Mode Control," Industrial Electronics, IEEE Transactions on, vol. 57. 6. pp. 1906-1913, 2010.

[5] N. A. Ahmed, "Computational Modelling and Polarization Characteristics of Proton-Exchange Membrane Fuel Cell with Evaluation of the Interface Systems," Journal of European Power Electronic, vol. 18. 1. pp. 32-41, March/April, 20082008.

[6] J. Larminie and A. Dicks, Fuel Cell Systems, Explained, 2 ed.: John Wiley \& Sons Inc., May 2003.

[7] S. K. Mazumder, K. Acharya, C. L. Haynes, R. Williams, Jr., M. R. von Spakovsky, D. J. Nelson, D. F. Rancruel, J. Hartvigsen, and R. S. Gemmen, "Solid-oxide-fuel-cell performance and durability: resolution of the effects of power-conditioning systems and application loads," Power Electronics, IEEE Transactions on, vol. 19. 5. pp. 1263-1278, 2004.

[8] C. Song-Yul, A. Jong-Woo, L. Jung-Gi, and B. Soo-Hyun, "Dynamic Simulator for a PEM Fuel Cell System With a PWM DC/DC Converter," Energy Conversion, IEEE Transactions on, vol. 23. 2. pp. 669-680, 2008.

[9] R. Vepa, "Adaptive State Estimation of a PEM Fuel Cell," Energy Conversion, IEEE Transactions on, vol. 27. 2. pp. 457-467.

[10] W. Caisheng and M. H. Nehrir, "Fuel cells and load transients," Power and Energy Magazine, IEEE, vol. 5. 1. pp. 58-63, 2007.

[11] K. Jeong and B. Oh, "Fuel Economy and Life-Cycle Cost Analysis of a Fuel Cell Hybrid Vehicle," Journal of Power Sources, vol. 105. pp. 5865, 2002.

[12] M. Uzunoglu and M. S. Alam, "Dynamic modeling, design and simulation of a PEM fuel cell/ultra-capacitor hybrid system for vehicular applications," Energy Conversion and Management, vol. 48. 5. pp. 1544-1553, 2007.

[13] C. A. Ramos-Paja, C. Bordons, A. Romero, R. Giral, and L. MartinezSalamero, "Minimum Fuel Consumption Strategy for PEM Fuel Cells," Industrial Electronics, IEEE Transactions on, vol. 56. 3. pp. 685-696, 2009.

[14] K. Yoon-Ho and K. Sang-Sun, "An electrical modeling and fuzzy logic control of a fuel cell generation system," Energy Conversion, IEEE Transactions on, vol. 14. 2. pp. 239-244, 1999. 